\title{
Spawning of migratory fish species between two reservoirs of the upper Uruguay River, Brazil
}

\author{
David A. Reynalte-Tataje ${ }^{1}$, Alex P. O. Nuñer ${ }^{1}$, Michele C. Nunes ${ }^{1}$, Valquíria Garcia ${ }^{1,2}$, \\ Carolina A. Lopes ${ }^{1,2}$ and Evoy Zaniboni-Filho ${ }^{1}$
}

This study investigated the migratory fish spawning within the reservoirs of the Machadinho and Itá dams (upper Uruguay River, Brazil) and its relationship to environmental variables. Sampling was conducted in the lotic region of the river in two sites between the dams' reservoirs: Uruguay (main river) and Ligeiro (tributary). Sampling included nine consecutive reproductive periods (RP) spanning the period from 2001 to 2010 and was conducted at night on the water surface using cylindrical-conical plankton nets $(0.5 \mathrm{~mm}$ mesh); environmental variables were also recorded. The spawning of the migratory species Salminus brasiliensis, Prochilodus lineatus, and Steindachneridion scriptum was registered: S. brasiliensis and $P$. lineatus spawned in the tributary river at the end of spring/beginning of summer, during flooding and during periods of high water temperature. Steindachneridion scriptum spawned in the main river at the beginning of spring. The study showed that S. brasiliensis, P. lineatus, and S. scriptum are able to spawn in small lotic river stretches within two reservoirs, but only under very specific and not common environmental conditions.

Este estudo verificou a presença de desova de peixes migradores entre os reservatórios das Usinas Hidrelétricas de Machadinho e Itá (alto rio Uruguai, Brasil), e sua relação com as variáveis ambientais. As amostragens foram realizadas na região lótica do rio Uruguai, no trecho situado entre os reservatórios de Itá e Machadinho, em duas estações de amostragem: Uruguai (Principal) e Ligeiro (Tributário). As coletas abrangeram nove períodos reprodutivos (PR) consecutivos, desde 2001 até 2010 , e foram realizadas no período noturno, na superfície, com o uso de redes de plâncton do tipo cilíndrico-cônicas de malha 0,5 $\mathrm{mm}$, quando também foram registradas as variáveis ambientais. O estudo registrou a desova de três espécies migradoras: Salminus brasiliensis, Prochilodus lineatus e Steindachneridion scriptum. As populações de S. brasiliensis e P. lineatus desovaram no rio tributário no final da primavera e início do verão em condições de enchentes e temperatura da água mais alta. Steindachneridion scriptum desovou no rio principal durante o início da primavera. O presente estudo mostra que $S$. brasiliensis, $P$. lineatus e $S$. scriptum conseguem desovar em pequenos trechos lóticos de rio entre dois reservatórios, porém em condições ambientais determinadas e pouco frequentes.

Key words: Ichthyoplankton, Temporal distribution, Water flow, Water temperature.

\section{Introduction}

The most common impact of changes associated with river damming on fish populations is the alteration in the composition and structure of species (Agostinho et al., 2004a): when damming occurs, it is expected that generalist and smaller species will proliferate rapidly first, while populations of migratory and larger species will decrease or disappear (Agostinho et al., 2007).
Two of the main reasons for the decrease of migratory fish populations following river damming are the reduction of the lotic environment and the changes in water flow (Humphries \& Lake, 2000; Carolsfeld et al., 2003). The reduction of the lotic environment to short stretches interferes directly on the migration. Migratory species also need environmental conditions that trigger migration, which in turn stimulate gonadal maturation and spawning (Vazzoler et al., 1997). Despite the existence of several triggers, one of the most important in

${ }^{1}$ Universidade Federal de Santa Catarina, Centro de Ciências Agrárias, Departamento de Aquicultura, Laboratório de Biologia e Cultivo de Peixes de Água Doce. Rodovia SC 406, 3532, 88066-000 Florianópolis, Santa Catarina, Brazil. reynalted@hotmail.com

${ }^{2}$ Universidade Federal de Santa Catarina, Centro de Ciências Agrárias, Departamento de Aquicultura, Programa de Pós-Graduação em Aquicultura. Rodovia Ademar Gonzaga, 1346, 88034-001 Florianópolis, Santa Catarina, Brazil. 
the Neotropical region is the increase in water flow during the rainy season, a condition that is strongly altered by river damming (Agostinho et al., 2004b). In rivers with cascade reservoirs, where there are no lotic stretches and/or such areas are short (Petts, 1989; Agostinho et al., 2007), the impact on the reproduction of migratory species is amplified.

The fish fauna in the upper Uruguay River basin, Brazil, which has been transformed by the construction of several dams, is characterized by the predominance of small and medium-sized species with external fecundation that do not migrate or present short reproductive migration, although large rheophilic species also occur (Reynalte-Tataje \& Zaniboni-Filho, 2008). Long reproductive migration of eight species occur within the river basin (ascendant and/or descendant), including Leporinus obtusidens, Prochilodus lineatus, Salminus brasiliensis, and Steindachneridion scriptum (Zaniboni-Filho \& Schulz, 2003). These species are found in the reservoir of the Itá Hydroelectric Power Plant (HPP), where fish movements are limited to a river stretch of $130 \mathrm{~km}$ that separates Itá and Machadinho dams, located upstream. Nevertheless, the reproduction of those species' remnant populations has not yet been confirmed within this reservoir, although many samples of migratory fish with mature gonads have already been captured (Reynalte-Tataje et al., 2008a).

Although the finding of mature gonads is a very significant event, the record of eggs is what truly confirms the spawning (Nakatani et al., 2001) and furthermore, studies related to eggs are essential to determine the moment and the areas where spawning takes place (Hempel, 1973). Such information is also important to indicate areas that should be protected and to the understanding of species' yearly recruitment when associated to larvae abundance (Nakatani et al., 2001; Reynalte-Tataje et al., 2008a).

Several studies on the ichthyoplanktonic community of the upper Uruguay River have been conducted over the past few years (Reynalte-Tataje et al., 2008a; Reynalte-Tataje et al., 2008b; Hermes-Silva et al., 2009), most of them related to egg and larvae distribution over space and time in the regions impacted by the reservoirs. These studies have confirmed the existence of spawning areas for sedentary species and/or species that perform short migrations in the region (Reynalte-Tataje et al., 2008c), but despite the increase in sampling effort in the recent years (Hermes-Silva et al., 2009; Correa et al., 2011), there is a continued lack of information on the spawning of large migratory species. It has never been reported either for the area influenced by the dams or for the entire region, what generated doubts about the existence of spawning in the region between the reservoirs of Itá and Machadinho.

This study analyzed ichthyoplankton in an attempt to answer two questions concerning the distribution of migratory fish species in the upper Uruguay River region: a) Do migratory species spawn in the small lotic stretch of $10 \mathrm{~km}$ between the Itá and Machadinho reservoirs? b) Which are the environmental conditions related to those spawning events?

\section{Material and Methods}

\section{Study area}

The upper Uruguay River is located in an extremely enclosed subtropical valley and does not present floodplains in its landscape. In the last decade, three reservoirs (Itá, Machadinho, and Foz do Chapecó) have been constructed in the main river (Uruguay), but none of those has a fish passage system.

The flood period is less evident in this region than in most Brazilian water basins. Although water levels may peak at different seasons, the highest rainfall rates occur historically at the end of winter and at the beginning of spring (September to October) while the summer months and the beginning of autumn (December to April) are driest (Sartori, 2003).

This study was conducted at the mouth of the Ligeiro River (27 $31^{\prime}$ 'S; $51^{\circ} 50^{\prime} \mathrm{W}$ ), an Uruguay River's tributary located $124 \mathrm{~km}$ upstream from the dam of the Itá HPP and $6 \mathrm{~km}$ downstream from the dam of Machadinho HPP. That tributary discharges into the single lotic stretch $(10 \mathrm{~km})$ of the Uruguay River between those HPP. Two sampling sites were installed in this region: Uruguay site, located in the Uruguay River (main river), a few meters upstream from the mouth of the Ligeiro River, and Ligeiro site, located $1 \mathrm{~km}$ upstream from the mouth of this river (Fig. 1).

\section{Sampling}

Sampling was conducted at night $(21: 00 \mathrm{~h})$ during nine reproductive periods (RP) from October to February, between years 2001 and 2010 (Table 1).

Five consecutive monthly samples were obtained from each station using conical-cylindrical plankton nets $(0.5 \mathrm{~mm}$ mesh) with a mouth area of $0.11 \mathrm{~m}^{2}$; a flow meter was attached to each net to measure the volume of water filtered. Sampling was conducted at the surface of the channel of the river with a boat dragging the net at low speed for $10 \mathrm{~min}$ (Hermes-Silva et al., 2009). When ichthyoplankton was sampled, the following environmental variables were also recorded for each sampling site: water temperature, dissolved oxygen, $\mathrm{pH}$, and water transparency. The data on precipitation and water flow were obtained from records provided by the Brazilian National Electricity Agency (ANEEL) and by the administration of the Itá and Machadinho HPP.

The living egg method, described by Reynalte-Tataje \& Zaniboni-Filho (2008), was used to sort the material. For that purpose, a mobile laboratory was set up near the sampling sites, where collected eggs were classified, under a stereomicroscope, into morphotypes accordingly to egg size, yolk size and coloration, presence of adhesive in the membrane, presence of a double membrane and distance between the external and internal membrane. Eggs of the same morphotype were then incubated in bags filled with water and oxygen and hatched larvae were used to confirm the eggs' identification, Identification of eggs and larvae followed Nakatani et al. (2001) and Reynalte-Tataje \& Zaniboni-Filho (2008). 


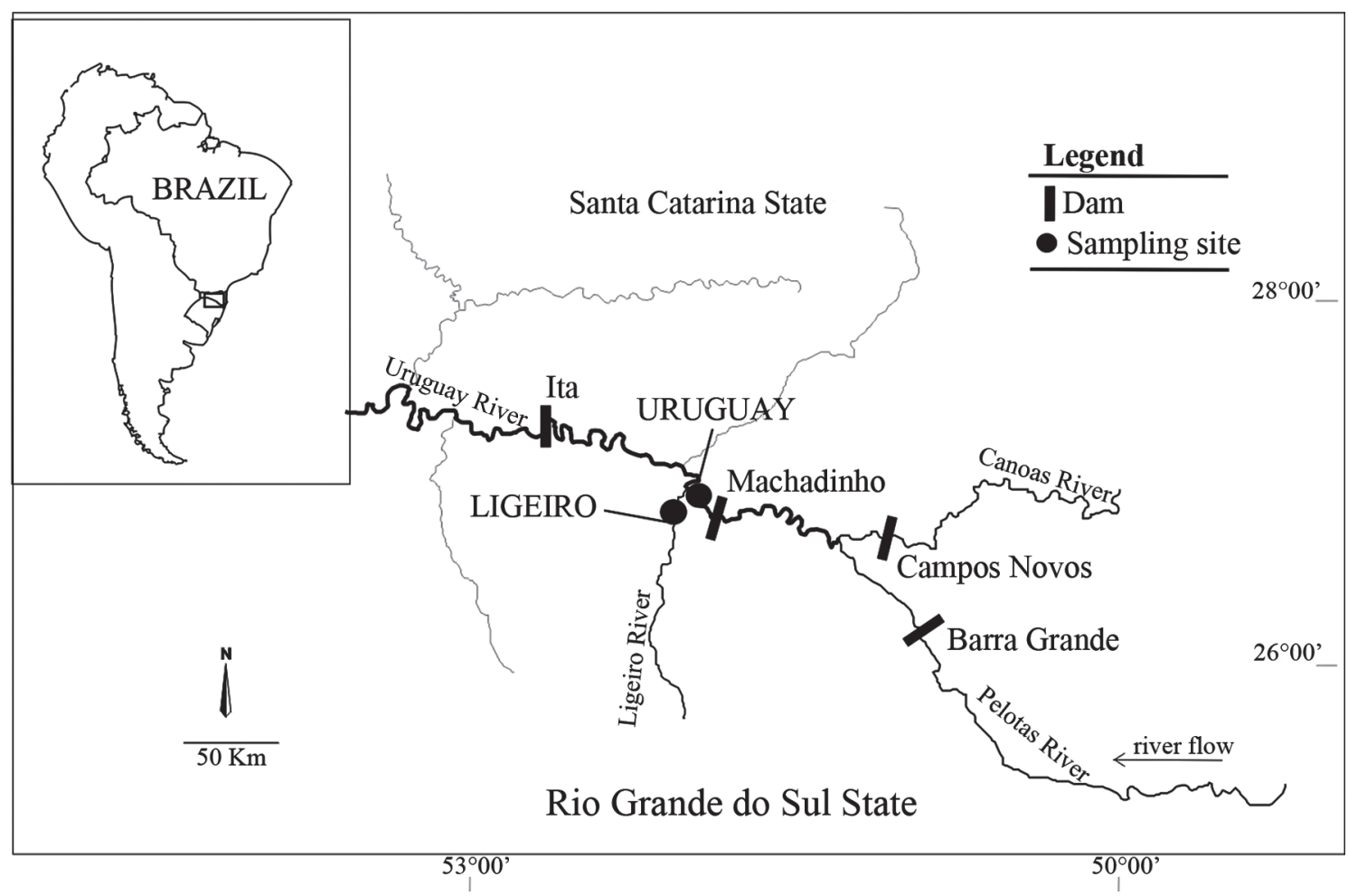

Fig 1. Map of sampling sites location. Uruguay = site in Uruguay River; Ligeiro = site in Ligeiro River.

\section{Data analysis}

Differences in total densities (eggs $/ 10 \mathrm{~m}^{3}$; fourth root transformed) among sites, months and reproductive periods were tested using the Kruskal-Wallis test, since collected data did not conform to normality or homogeneity of variances. When necessary, the post hoc Dunn's test was applied to identify group differences (Zar, 1996).

Principal component analysis (PCA) was used to identify the environmental variables that characterize the studied environments; for this analysis all variables, except $\mathrm{pH}$, were $\log$ transformed $\left(\log _{10}\right)$ to linearize inter-variable relationships (Peters, 1986). The axes with eigenvalues greater than those generated randomly were retained for interpretation, following the broken-stick model criteria (Jackson, 1993) and only environmental variables with

Table 1. Beginning and end of sampling during the different reproductive periods (RP).

\begin{tabular}{ccc}
\hline & \multicolumn{2}{c}{ Reproductive Periods } \\
\cline { 2 - 3 } Code & Beginning & End \\
\hline RP1 & October $/ 2001$ & February $/ 2002$ \\
RP2 & October $/ 2002$ & February $/ 2003$ \\
RP3 & October $/ 2003$ & February $/ 2004$ \\
RP4 & October $/ 2004$ & February $/ 2005$ \\
RP5 & October $/ 2005$ & February $/ 2006$ \\
RP6 & October $/ 2006$ & February $/ 2007$ \\
RP7 & October $/ 2007$ & February $/ 2008$ \\
RP8 & October $/ 2008$ & February $/ 2009$ \\
RP9 & October $/ 2009$ & February $/ 2010$ \\
\hline
\end{tabular}

structure coefficients greater than 0.4 were used in interpretation, since they show the greatest correlation with the axis (Legendre \& Legendre, 1998).

The correlation between the number of eggs of the different migratory species captured in the distinct reproductive periods was expressed by the Spearman's correlation coefficient.

\section{Results}

\section{Migratory species composition}

During the studied period, 182.60 eggs $/ 10 \mathrm{~m}^{3}$ (7,138 eggs) of migratory species were captured, that represented $5.8 \%$ of the total captured eggs. Of this total, 179.08 eggs $/ 10 \mathrm{~m}^{3}(7,098$ eggs) belonged to Salminus brasiliensis, $1.40 \mathrm{eggs} / 10 \mathrm{~m}^{3}$ (38 eggs) to Prochilodus lineatus and 2.12 eggs $/ 10 \mathrm{~m}^{3}$ (6 eggs) to Steindachneridion scriptum.

Of the total eggs captured, $180.48 \mathrm{eggs} / 10 \mathrm{~m}^{3}$ were caught in the Ligeiro River and 2.12 eggs $/ 10 \mathrm{~m}^{3}$ were captured in the Uruguay River. However, S. scriptum eggs were only caught in the Uruguay River, while $S$. brasiliensis and P. lineatus eggs were captured only in the Ligeiro River.

Steindachneridion scriptum eggs were captured during RP1 and RP2, between the months of October and November, whereas $P$. lineatus eggs were sampled during RP2 and RP8 (between November and December) and $S$. brasiliensis eggs were caught during RP2, RP8, and RP9 (between November and January). Most captured eggs were in the initial stage of 
development (recently fertilized or segmentation stages), however eggs of the $S$. scriptum were in a more advanced stage (free tail).

\section{Spatial and temporal distribution of eggs}

Although over $99 \%$ of the eggs were captured in the Ligeiro River, the Kruskal-Wallis test did not indicate any statistically significant difference between the numbers of eggs captured in the Ligeiro and Uruguay rivers $(\mathrm{H}(1, \mathrm{~N}=150)=$ 2.93; $\mathrm{P}>0.05$; Fig. 2). A statistically significant difference $(\mathrm{P}<0.05)$ in the abundance of eggs in the different reproductive periods was found $(\mathrm{H}(8, \mathrm{~N}=350)=20.91 ; \mathrm{P}<0.05$; Fig. 3a), with the greatest abundance recorded in RP9 (Dunn's test; $\mathrm{P}<0.05$ ). Nevertheless, no statistically significant difference was found for the distribution of eggs throughout the months of the year $(\mathrm{H}(4, \mathrm{~N}=350)=3.85 ; \mathrm{P}>0.05$; Fig. $3 \mathrm{~b})$.

A significant relationship between the abundance of $P$. lineatus and $S$. brasiliensis $(\mathrm{r}=0.51 ; \mathrm{P}<0.05)$ was registered when data from all reproductive periods were used.

\section{Influence of environmental variables}

During the study period, no extreme values were registered for the environmental variables (Table 2).

The PCA showed that only axis 1 , that has an eigenvalue of 2.28 and represented $52.0 \%$ of the total variance, can be retained for interpretation, with the variables water temperature and water flow being the most representative (Table 3 ). The segregation between the main river and the tributary throughout the study period is clearly shown in Fig. 4.

Mean monthly values of water temperature and water flow in Ligeiro River during the reproductive periods are shown in Fig. 5, where the densities of $P$. lineatus and $S$. brasiliensis captured eggs were superimposed. This combination showed that $P$. lineatus and $S$. brasiliensis eggs were captured only when water temperature exceeded $22^{\circ} \mathrm{C}$ and water flow was higher than $100 \mathrm{~m}^{3} / \mathrm{s}$.

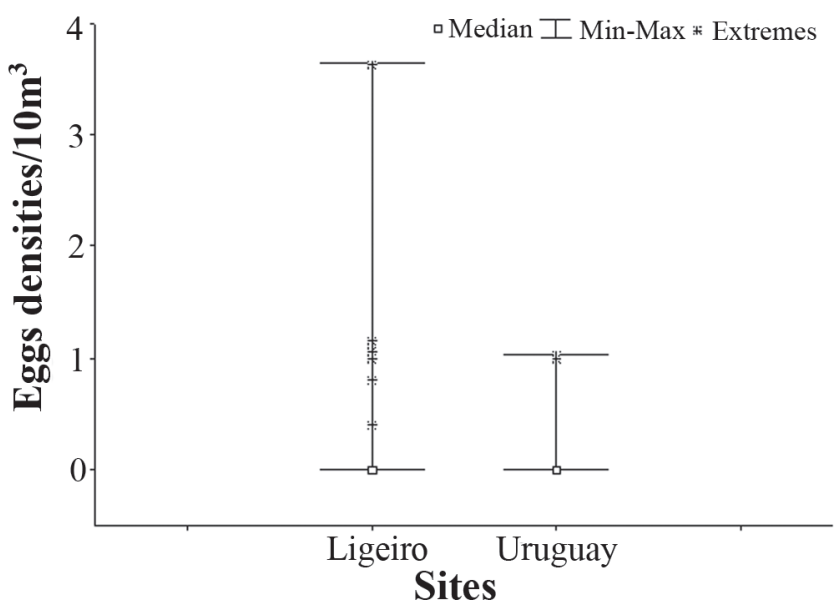

Fig 2. Density of eggs (transformed by $\sqrt[4]{\text { egg density }) ~ c a p t u r e d ~}$ in the Uruguay and Ligeiro Rivers from October 2001 to February 2010.

\section{Discussion}

The upper Uruguay River is one of the regions of the Prata basin for which the spawn of migratory fish or the presence of the larvae of those species had not been reported previously. After the damming of Uruguay River for the construction of hydroelectric power plants many studies were conducted to verify whether migratory species continued to breed in that area (Zaniboni-Filho \& Schulz, 2003; Reynalte-Tataje et al., 2008b; Hermes-Silva et al., 2009). Some of them indicated that some migratory fish species reach the stage of gonadal maturity, but as eggs and larvae were not recorded, the spawning in the region was not confirmed (Reynalte-Tataje et al., 2008c). As some authors believe that the absence of free areas and/or the presence of short river stretches can harm the reproduction of migratory species (Godoy, 1975; Barthem \& Goulding, 1997), the prevalent hypothesis is that migratory species
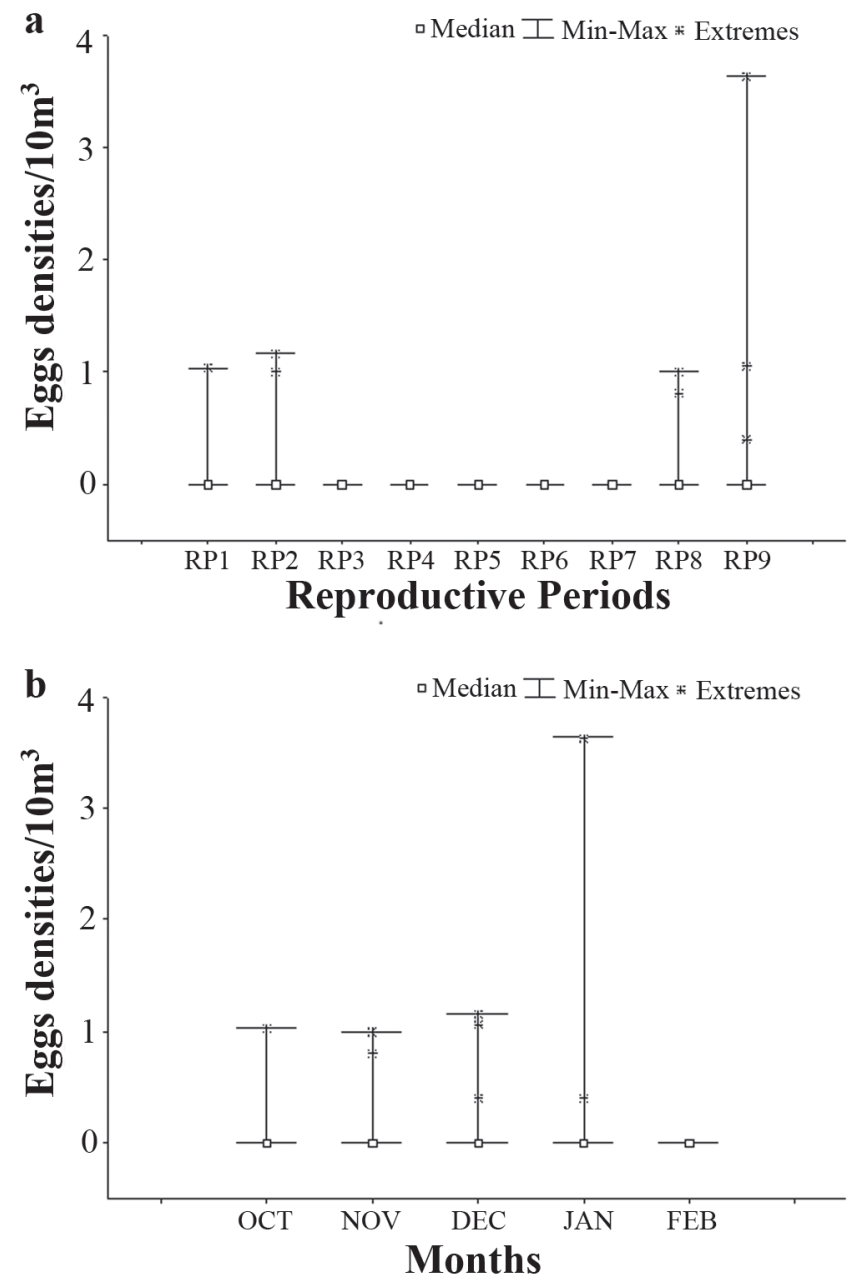

Fig 3. Density of eggs (transformed by $\sqrt[4]{\text { egg density }) ~ c a p t u r e d ~}$ in the Uruguay and Ligeiro Rivers from October 2001 to February 2010: (a) during different reproductive periods (RP); (b) in different months. 
Table 2. Mean values (minimum-maximum) of environmental variables measured at the Ligeiro and Uruguay Rivers between October 2001 and February 2010.

\begin{tabular}{ccccccc}
\hline River & $\begin{array}{c}\text { Water temperature } \\
\left({ }^{\circ} \mathrm{C}\right)\end{array}$ & $\begin{array}{c}\text { Dissolved oxygen } \\
\left(\mathrm{mg} \cdot 1^{-1}\right)\end{array}$ & $\mathrm{pH}$ & $\begin{array}{c}\text { Secchi depth } \\
(\mathrm{cm})\end{array}$ & $\begin{array}{c}\text { Water flow } \\
\left(\mathrm{m}^{3} \cdot \mathrm{s}^{-1}\right)\end{array}$ & $\begin{array}{c}\text { Precipitation } \\
(\mathrm{mm})\end{array}$ \\
\hline Ligeiro & 23.99 & 7.64 & 7.52 & 73 & 94 & $(8-397)$ \\
(width: 60m, depth: $2.5 \mathrm{~m})$ & $(17.50-29.10)$ & $(4.45-10.54)$ & $(6.01-8.69)$ & $(5-200)$ & 4.9 \\
\hline Uruguay & 22.15 & 7.27 & 7.32 & 116 & 701 & $(0.5-11.3)$ \\
(width: 250m, Depth: 6.0m) & $(16.40-26.10)$ & $(4.15-10.95)$ & $(6.51-9.11)$ & $(35-260)$ & $(269-2098)$ & \\
\hline
\end{tabular}

Table 3. Correlations of environmental variables with Principal Component 1 ( $\mathrm{PC} 1)$, eigenvalue and the respective percentage of explanation. Values greater than 0.4 are in bold.

\begin{tabular}{lc}
\hline Variables & PC1 \\
\hline Water temperature $\left({ }^{\circ} \mathrm{C}\right)$ & $\mathbf{0 . 6 2}$ \\
pH & 0.22 \\
Dissolved oxygen $\left(\mathrm{mg} . \mathrm{L}^{-1}\right)$ & -0.09 \\
Flow $\left(\mathrm{m} . \mathrm{s}^{-1}\right)$ & $\mathbf{- 0 . 5 4}$ \\
Transparency $(\mathrm{cm})$ & -0.32 \\
\hline Eigenvalues & 2.28 \\
\% of explanation & 52.0 \\
\hline
\end{tabular}

failed to spawn in upper Uruguay River, since it is influenced by damming and by the absence of long free stretches of river. However, in the present study, eggs and larvae of migratory fish species were eventually captured in the short $(<10 \mathrm{~km})$ lotic stretch between the Itá Reservoir and the Machadinho Dam.

The identification of $S$. brasiliensis and P. lineatus eggs in initial developmental stages at the mouth of Ligeiro River indicated that spawning probably occurred in the lower region of this tributary. Studies conducted in this region indicate that other sedentary or short-distance migratory species are able to complete their embryonic and even larval development in this same river stretch (Reynalte-Tataje et al., 2008b; Reynalte-Tataje et al., 2008c).

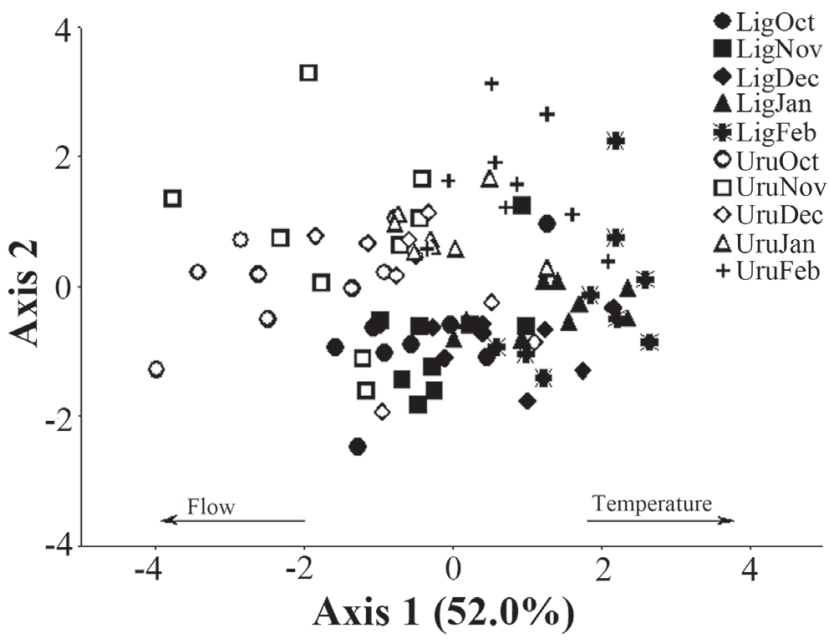

Fig 4. Principal Component Analysis (PCA) of the matrix of environmental variables recorded at the Uruguay and Ligeiro Rivers from October 2001 to February 2010.
The capture of very few S. scriptum eggs in the Uruguay River site was the first record of this species in ichthyoplankton for that region, indicating that this species can use the $6 \mathrm{~km}$ stretch between the Machadinho Dam and the mouth of the Ligeiro River to spawn. Since all S. scriptum eggs were captured in the free tail stage, a final stage in the larvae development, the embryonic development of this species must occur within this short river stretch. However, the small number of $S$. scriptum eggs captured in RP1 and RP2 periods suggests that their reproduction in the region is very limited.

The relationship of teleosteans' reproductive activity with environmental variables, in addition to control by endogenous factors, has been reported by several authors (Sato et al., 2003; Reynalte-Tataje et al., 2008a). According to Parkinson et al. (1999), while water flow and water temperature initiate spawning migration, reproductive success may be linked to water volume and temperature. In the upper Uruguay River, the increase in water flow that commonly occurs in the spring, which is considered the flood period, reduces water temperature drastically and impairs spawning, whereas in the summer the reduction of water flow promotes a substantial increase in water temperature. However, the interannual variation in the spawning of $P$. lineatus and $S$. brasiliensis at

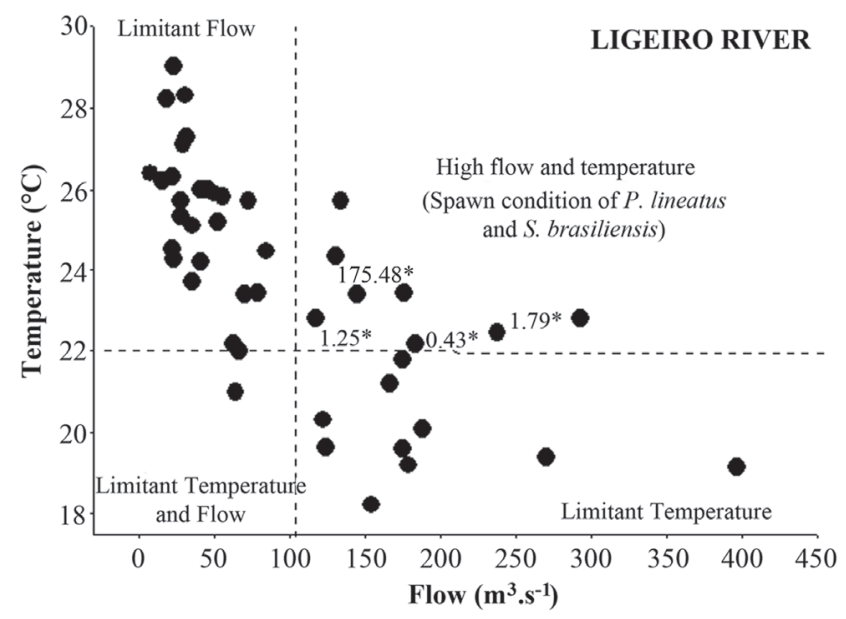

Fig 5. Mean monthly values for water flow and water temperature of the Ligeiro River during reproductive periods from October 2001 to February 2010. *Density of Prochilodus lineatus and Salminus brasiliensis captured eggs (1.79 eggs/ $10 \mathrm{~m}^{3}$ in Dec/2003; Nov/08 $=0.43 \mathrm{eggs} / 10 \mathrm{~m}^{3}$ in Nov $/ 2008 ; 1.25$ eggs $/ 10 \mathrm{~m}^{3}$ in Dec/2009; 175.48 eggs $/ 10 \mathrm{~m}^{3}$ in Jan/2010). The value in bold indicates only $S$. brasiliensis spawn. 
Table 4. Climatic phenomena present during the reproductive periods (RP) at the Ligeiro River from October 2001 to March 2010. *Intensity: +: weak; ++: moderate; **Density: $+: \leq 10$ eggs $/ 10 \mathrm{~m}^{3} ;++:>10 \mathrm{eggs} / 10 \mathrm{~m}^{3}$.

\begin{tabular}{|c|c|c|c|c|c|c|}
\hline \multicolumn{7}{|l|}{ 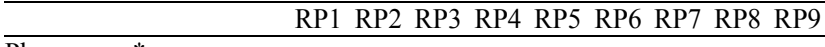 } \\
\hline Phenomena*: & & & & & & \\
\hline "El Niño" & & ++ & + & + & & ++ \\
\hline SACZ & + & + & & & + & \\
\hline Eggs of migratory fish $* *$ : & + & + & & & + & ++ \\
\hline
\end{tabular}

upper Uruguay River was related to very specific conditions of high water flow and high water temperature. This rare condition may be related to moderate "El Niño" events, during which water temperature and flow increase significantly in the region (Monteiro, 2001); and to the South Atlantic Convergence Zone (SACZ), which promotes an increase in precipitation in the region of the upper Uruguay River during spring and summer (Nery, 2005; Mendonça \& Bonatti, 2008). Both environmental conditions were registered in the reproductive periods where spawns of migratory fish occurred (Table 4). According to Reynalte-Tataje et al. (2008a), after the construction of dams in the region, water temperature decreased by at least $2^{\circ} \mathrm{C}$ in the lotic environments located below the Machadinho and Itá Dams. Thus, those species spawned in the years in which flooding did not reduce water temperature to less than $22^{\circ} \mathrm{C}$, which provided the physiological conditions necessary for spawning. The absence of spawns in some years with apparently ideal environmental conditions can be related to the low abundance of migratory fish in the study area or to the difficulty of finding the fish during spawning, as it occurs at specific times and not during the entire reproductive period (Lowe-McConnell, 1999; Zaniboni-Filho \& Nuñer, 2004).

The presence of lotic stretches in cascade reservoirs is recognized for its importance in the reproduction and recruitment of migratory species. In the present study, the short lotic stretch between Itá Reservoir and Machadinho Dam enabled the spawning, but only when a very specific environmental condition occurred. Despite of that, abundance of eggs of migratory fish was not high and the observed spawns were sporadic, with large interannual variation. Such spawning however, does not guarantee that recruitment will be successful, since it will depend on the success of incubation during egg drift and on the availability of adequate nursery environments for larvae and juveniles, conditions that seems to be absent in the area, since larvae of migratory species has never been found in the region (Correa et al., 2011; Reynalte-Tataje et al., 2012).

\section{Acknowledgments}

The authors thank the coworkers from Laboratório de Biologia e Cultivo de Peixes de Água Doce for their help in field sampling and sample sorting. This work is part of the project "Monitoring and management of the ichthyofauna at
Itá and Machadinho Hydroelectric Power Plant", supported by Tractebel Energia, Consórcio Itá and Consórcio Machadinho. Graduate and undergraduate scholarships were provided by CAPES and CNPq.

\section{Literature Cited}

Agostinho, A. A., S. M. Thomaz \& L. C. Gomes. 2004a.Threats for biodiversity in the floodplain of the Upper Paraná River: effects of hydrological regulation by dams. Ecohydrology \& Hydrobiology, 4: 255-268.

Agostinho, A. A., L. C. Gomes, S. Veríssimo \& E. K. Okada. 2004b. Flood regime, dam regulation and fish in the Upper Paraná River: effects on assemblage attributes, reproduction and recruitment. Reviews in Fish Biology and Fisheries, 14:11-19.

Agostinho, A. A., L. C. Gomes \& F. M. Pelicice. 2007. Ecologia e Manejo de Recursos Pesqueiros em Reservatórios do Brasil. Maringá, EDUEM, 501p.

Barthem, R. \& M. Goulding. 1997. The catfish connection: ecology, migration and conservation of Amazon predators. New York, Columbia University Press, 130p.

Carolsfeld, J., B. Harvey, A. Baer \& C. Ross. 2003. Migratory fishes of the South América: biology, social importance and conservation status. Victoria, World Fisheries Trust, 372p.

Côrrea, R. N., Hermes-Silva, S., Reynalte-Tataje, D., ZaniboniFilho, E. 2011. Distribution and abundance of fish eggs and larvae in three tributaries of the Upper Uruguay River (Brazil). Environmental of Biology Fishes, 91:51-61.

Godoy, M. P. 1975. Peixes do Brasil, Subordem Characoidei: bacia do rio Mogi Guaçu. Piracicaba, Ed. Franciscana, 4: 631-831.

Hempel, G. 1973. Fish egg and larval surveys. FAO Fisheries Technical Paper, 122: 82.

Hermes-Silva, S., D. A. Reynalte-Tataje \& E. Zaniboni-Filho. 2009. Spatial and Temporal Distribution of Ichthyoplankton in the Upper Uruguay River, Brazil. Brazilian Archives of Biology and Technology, 52: 933-944.

Humphries, P. \& P. S. Lake. 2000. Fish larvae and management of regulated Rivers. Regulated Rivers: Research \& Management, 16: 421-432.

Jackson, D. A. 1993. Stopping rules in principal components analysis: a comparison of heuristical and statistical approaches. Ecology, 74: 2204-2214.

Legendre, P. \& L. Legendre. 1998. Numerical Ecology. Amsterdam: Elsevier, 853p.

Lowe-McConnell, R. H. 1999. Ecological Studies in Tropical Fish Communities. São Paulo: Editora da Universidade de São Paulo, 534p.

Mendonça, R. W. \& J. P. Bonatti. 2008. Study of the modal energetics for SACZ episodes. Part II. Impact of the model resolution and the connection parameterization. Revista Brasileira de Meteorologia, 23: 381-403.

Monteiro, M. A. 2001. Caracterização climática do estado de Santa Catarina: uma abordagem dos principais sistemas atmosféricos que atuam durante o ano. Geosul,16: 69-78.

Nakatani, K., A. A. Agostinho, G. Baumgartner, A. Bialetzki, P. V. Sanches, M. C. Makrakis, C. S. Pavanelli. 2001. Ovos e larvas de peixes de água doce: desenvolvimento e manual de identificação. Maringá, EDUEM, 349p.

Nery, J. T. 2005. Dinâmica climática da região Sul do Brasil. Revista Brasileira de Climatologia, 1: 61-75.

Parkinson, D., J. C. Philipport, E. A. Baras. 1999. A preliminary investigation of spawning migration of grayling in a small stream 
as determined by radio-tracking. Journal of Fish Biology, 55: 172-182.

Peters, R. K. 1986. The role of prediction in limnology. Limnology and Oceanography, 31: 1143-1159.

Petts, G. E. 1989. Perspectives for ecological management of regulated rivers. Pp. 3-24. In: Gore, J. A. \& G. E. Petts (Eds.). Alternatives in regulated river management. Florida, CRC Press, $344 \mathrm{p}$.

Reynalte-Tataje, D. A., S. Hermes-Silva, L. A. Weiss \& E. ZaniboniFilho. 2008a. Distribuição e abundância temporal do ictioplâncton no alto rio Uruguai, Brasil. Pp. 195-228. In: Zaniboni-Filho, E. \& A. P. O. Nuñer (Eds.). Reservatório de Itá. Estudos ambientais, desenvolvimento de tecnologia e conservação da ictiofauna. Florianópolis, Editora UFSC, 319p.

Reynalte-Tataje, D. A., S. Hermes-Silva, M. M. Carvalho-Silva, F. M. Abbud, R. N. Correa \& E. Zaniboni-Filho. 2008b. Distribuição de ovos e larvas de peixes na área de influência do reservatório de Itá (Alto rio Uruguai). Pp. 127-158. In: ZaniboniFilho, E. \& A. P. O. Nuñer (Eds.). Reservatório de Itá. Estudos ambientais, desenvolvimento de tecnologia e conservação da ictiofauna. Florianópolis, Editora UFSC, 319p.

Reynalte-Tataje, D. A., S. Hermes-Silva, P. A. da Silva, A. Bialetzki, \& E. Zaniboni-Filho. 2008c. Locais de crescimento de larvas de peixes na região do Alto Rio Uruguai (Brasil). Pp. 159-194. In: Zaniboni-Filho, E. \& A. P. O. Nuñer (Eds.). Reservatório de Itá. Estudos ambientais, desenvolvimento de tecnologia e conservação da ictiofauna. Florianópolis, Editora UFSC, 319p.

Reynalte-Tataje, D. A. \& E. Zaniboni-Filho. 2008. Biologia e identificação de ovos e larvas de peixes do alto rio Uruguai. Pp. 229256. In: Zaniboni-Filho, E. \& A. P. O. Nuñer (Eds.). Reservatório de Itá. Estudos ambientais, desenvolvimento de tecnologia e conservação da ictiofauna. Florianópolis, Editora UFSC, 319p.
Reynalte-Tataje, D. A., Agostinho, A. A., Bialetzki, A., HermesSilva, S. 2012. Spatial and temporal variation of the ichthyoplankton in a subtropical river in Brazil. Environmental of Biology Fishes, 94: 403-419.

Sartori, M. da B. G. 2003. A dinâmica do clima do Rio Grande do Sul: indução empírica e conhecimento científico. Terra livre, 20 : 27-49.

Sato, Y., N. Bazzoli, E. Rizzo, M. B. Boschi, M. O. T. Miranda. 2003. Impacto a jusante do reservatório de Três Marias sobre a reprodução do peixe reofílico curimatá-pacu (Prochilodus argenteus). Pp. 327-345. In: Godinho, H. P. \& A. L. Godinho (Eds.). Águas, peixes e pescadores do São Francisco das Minas Gerais. Belo Horizonte, PUC Minas, 458p.

Vazzoler, A. E. A. M., M. A. P. Lizama \& P. Inada. 1997. Influências ambientais sobre a sazonalidade reprodutiva. Pp. 267-280. In: Vazzoler, A. E. A. M., A. A. Agostinho \& N. S. Hahn (Eds.). A planície de inundação do alto rio Paraná: aspectos físicos, biológicos e socioeconômicos. Maringá, EDUEM, 460p.

Zaniboni-Filho, E. \& Schulz, U. H. 2003. Migratory Fishes of the Uruguay River. Pp. 157-194. In: Carolsfeld, J., B. Harvey, A. Baer \& C. Ross (Eds.). Migratory fishes of the South America: biology, social importance and conservation status. Victoria, World Fisheries Trust, 372p.

Zaniboni-Filho, E. \& Nuñer, A. P. O. 2004. Fisiologia da reprodução e propagação artificial dos peixes. Pp. 45-73. In: Cyrino, J. E. P., E. C. Urbinati, D. M. Fracalossi \& N. Castagnolli (Eds.). Tópicos Especiais em Piscicultura de Água Doce Tropical Intensiva. São Paulo, TecArt, 533p.

Zar, J. H. 1996. Biostatistical analysis. New Jersey, Prentice Hall, $662 p$.

Submitted August 3, 2011

Accepted July 21, 2012 